\title{
IL6R wt Allele
}

National Cancer Institute

\section{Source}

National Cancer Institute. IL6R wt Allele. NCI Thesaurus. Code C51368.

Human IL6R wild-type allele is located in the vicinity of $1 \mathrm{q} 21$ and is approximately $64 \mathrm{~kb}$ in length. This allele, which encodes interleukin- 6 receptor subunit alpha protein, plays a role in the mediation of both the immune response and hematopoiesis. 